DOI: $10.17805 /$ trudy.2016.2.7

\title{
ВОСТОЧНОСЛАВЯНСКИЙ БОЕВОЙ ПЛЯС: ОТ БОЯ - К ИСКУССТВУ
}

\author{
A. А. Чистякова \\ (Московский гуманитарный университет)
}

Аннотация: В статье дается краткое описание особенностей восточнославянского ритуала боевого пляса.

Ключевые слова: боевой пляс; история танца; воинские традиции; восточные славяне; ритуал поединка

\section{EAST SLAVIC WAR DANCE: FROM FIGHTING TO ART}

\author{
A. A. Chistyakova \\ (Moscow University for the Humanities)
}

\begin{abstract}
The article provides a brief description of the East Slavic ritual of war dance

Keywords: war dance; history of dancing; martial traditions; East Slavs; combat ritual
\end{abstract}

Россия имеет богатые воинские традиции. Славяне известны всей Европе как доблестные воины. В течение многих столетий русским людям приходилось постоянно защищаться и выдерживать натиск многочисленных соседей - хазаров, печенегов, половцев, монголо-татар, турок, немецких рыцарей, литовцев, поляков, шведов, французов, немцев. Войны на Руси были частым явлением, поэтому каждому мужчине следовало владеть ратными навыками.

Уже на первоначальной стадии развития государственности в России формируются самобытные национальные боевые традиции (см.: Чистякова, 2015). Начиная с самого раннего возраста, дети с помощью разнообразных игр и забав постепенно приучались к тому, что нужно уметь постоять за Родину, семью и самих себя. Одной из популярных форм боевой подготовки у восточных славян является боевой пляс - своеобразная боевая практика, тренировка, где в плясе закаляется сила духа, и вырабатываются специфические двигательные навыки.

Древний обычай ритуальных поединков является неотъемлемой ча- 
стью военно-траурной и календарно-праздничной обрядности. Пляска «под задор» («под драку») обязательный ритуал праздничного гуляния - отсутствие ее воспринималось как недостаток. Пляски «под драку» на свадьбах, больших календарных праздниках, изначально символизировали борьбу природных сил. На такие поединки борцы приходили без доспехов, часто противники дрались вообще обнаженными по пояс.

Со временем боевой пляс приобрел развлекательный характер молодецких состязаний и потех. Парни или молодые мужчины соревновались в силе, выносливости, ловкости, в мастерстве исполнения плясовых движений и изобретательности (по количеству, оригинальности движений), владении техническими приемами рукопашного боя.

Пляска начинается с «прикалывания» конкурирующих сторон, возглавляемых атаманами и музыкантами (задирания и стращания с помощью частушек, намеренного задевание друг друга в плясе). Далее следует парный или групповой боевой пляс, переходящий в рукопашный бой, под непрерывное инструментальное сопровождение и частушки зрителей. С прерыванием музыки борьба строго прекращается (в последней частушке обращаются к музыкантам с просьбой о завершении состязания). В борьбе обязательно соблюдаются нравственные правила боя, не допускается нанесение увечий и проявление злобы со стороны участников.

Важную роль в состязании играет гармонист: иногда искусство гармошечной игры заранее предвосхищало исход схватки. В народе говорили: «У кого гармошка лучше взяла, значит уже, считай, победа будет. А если у них слабонька, значит компания слабонька». Основу боевого пляса составляют общерусские плясовые движения: ходы, припляс, ковырялочка, моталочка, подбивка, хлопки и хлопушки, прыжки и др. Среди них обязательными элементами являются: «ломание» (или «буза») и пляска вприсядку (Базлов, а, Электр. ресурс). «Выламывание»- специфический элементом боевого пляса, содержащий приемы кулачного боя. Исполнитель сознательно пляшет, нарушая своими движениями ритм пляски и гармонию музыки. Выпадая из общего ритма окружающего мира, разрушая рамки своего привычного восприятия, пляшущий начинает видеть все иначе, как бы со стороны, таким образом, он входит в особое боевое состояние сознания «плын».

Пляска вприсядку представляет собой различные трюки, верчения, неожиданные подсечки, скачки и сопровождается присвистами и выкриками танцующих. Она служит подготовкой бойца к сражению лежа, сидя и на корточках. Авторитетный исследователь русских военных традиций Г.Н. Базлов поясняет: «Упавший с коня всадник, используя технику боя вприсядку, мог уйти от сабельного удара, выбить из седла противника и завладеть его конем, проскочить под брюхом идущей лошади подрезая 
ей паховину. В пешем бою применялся для боя в толкучке и в случае падения на землю» (Базлов, b, Электр. ресурс).

Традиции боевого пляса были распространены по всей России. Наиболее полно они сохранились в казачьей среде. Особую, священную ценность для воинов имеет оружие - знак казачьего достоинства и власти. Традиционным снаряжением казака является шашка, нагайка, пика и кинжал. Оружие находится в центре всех основных моментов жизни юноши-воина. В 8 лет казак начинает знакомиться с техникой владения нагайкой, что сопровождалось ритуалом переселения мальчика на мужскую половину дома. С 12 лет казачонка приучают к боевому оружию шашке и кинжалу. С этого периода он имеет почетное право тренироваться в последней линии построения вместе с взрослыми казаками. В играх и учениях казаков боевая шашка заменяется палкой.

Таким образом, пляска в подготовке воинов выполняет ряд ключевых функций: закладывает основы физической и психической подготовки казака для личной защиты и поражения противника, формирует патриотические чувства, военный дух, воспитывает моральные качества.

\section{СПИСОК ЛИТЕРАТУРЫ}

Базлов Г. Н. (а) История боевой пляски вприсядку [Электронный ресурс] // Буза Русская. Народная традиция рукопашного боя. URL: http:// www.buza.ru/text.php?cat_id=6\&text_id=30 (дата обращения: 12.11.2015).

Базлов Г.Н. (b) О боевом народном танце [Электронный ресурс] // Буза Русская. Народная традиция рукопашного боя. URL: http://www.buza.ru/ text.php?cat_id=6\&text_id=31 (дата обращения: 12.11.2015).

Чистякова, А. А. (2015) Русская традиционная танцевальная культура: истоки и современность [Электронный ресурс] // Научные труды Московского гуманитарного университета. № 5. URL: http://journals.mosgu. ru/trudy/article/view/144 (дата обращения: 12.01.2016). DOI: 10.17805/ trudy.2015.5.7

Чистякова Анастасия Александровна - доцент кафедры культуры и искусств Московского гуманитарного университета. Адрес: 111395 , Россия, г. Москва, ул. Юности, д. 5. Тел.: +7 (499) 374-59-40. Эл. адрес: $3730014 @$ mail.ru

Chistyakova Anastasiya Aleksandrovna, Associate Professor, Department of Culture and Art, Moscow University for the Humanities. Postal address: 5 Yunosti St., Moscow, Russian Federation 111395. Tel.: +7 (499) 374-59-40. E-mail: 3730014@mail.ru 